Marquette University

e-Publications@Marquette

Mechanical Engineering Faculty Research and

Publications

Engineering, College of

8-15-2012

\title{
Mechanism State Matrices for Spatial Reconfigurable Mechanisms
}

Philip A. Voglewede

Marquette University, philip.voglewede@marquette.edu

Brian Korves

Marquette University

Brian Slaboch

Marquette University

Published as part of the proceedings of the conference ASME 2012 International Design Engineering Technical Conferences \& Computers and Information in Engineering Conference. 
DETC2012-71361

Technical Publication

Mechanism State Matries For Spatial Reconfigurable Mechanisms

\section{Authors}

Brian Korves, Marquette University

Brian Slaboch, Marquette University

Philip Voglewede, Marquette University

\section{Abstract}

This paper improves augmented mechanism state matrices by replacing joint code with screw system notation. The proposed substitution allows for a more specific description of the joints in the mechanism and the capability to describe both spatial and planar mechanisms. Examples are provided which elucidate the proposed approach.

Session: MR-1-7 Deployable and Reconfigurable Mechanisms

Close Window 